\title{
Investigations with GMC2021 in experimental models predictive of antimigraine activity and coronary side-effect potential
}

\author{
Pramod R. Saxena ${ }^{\text {a, }}$, Peter De Vries ${ }^{\text {a }}$, Jan P.C. Heiligers ${ }^{a}$, \\ Antoinette MaassenVanDenBrink ${ }^{a}$, Willem A. Bax ${ }^{a}$, Tjeerd Barf ${ }^{b}$, Håkan Wikström $^{b}$ \\ a Department of Pharmacology, Cardiovascular Research Institute 'COEUR', Faculty of Medicine and Health Sciences, Erasmus University Rotterdam \\ and Dutch Migraine Research Group, P.O. Box 1738, 3000 DR Rotterdam, Netherlands \\ ${ }^{b}$ Department of Medicinal Chemistry, Faculty of Pharmacy, The State University, Antonius Deusinglaan 2, 9713 AW Groningen, Netherlands
}

Received 19 February 1996; revised 29 May 1996; accepted 7 June 1996

\begin{abstract}
Several acutely acting antimigraine drugs, including sumatriptan and other second generation $5-\mathrm{HT}_{1 \mathrm{D}}$ receptor agonists, have the ability to constrict porcine carotid arteriovenous anastomoses as well as the human isolated coronary artery. These two experimental models seem to serve as indicators, respectively, for the therapeutic and coronary side-effect potential of the compounds. Using these two models, we have now investigated the effects of GMC2021 (3-[2-(dimethylanimo)ethyl]-5-[(trifluoromethyl)sulfonyl]oxy][1 $H$ ]indole oxalate, a close analogue of sumatriptan. GMC2021 $\left(30,100,300\right.$ and $1000 \mu \mathrm{g} \cdot \mathrm{kg}^{-1}$, i.v. ) decreased the total carotid blood flow by exclusively decreasing arteriovenous anastomotic blood flow; capillary blood flow to the skin and ears was moderately increased. The mean \pm S.E.M. dose of GMC2021 eliciting a 50\% decrease $\left(\mathrm{ED}_{50}\right)$ in the porcine carotid arteriovenous anastomotic blood flow was found to be $1.1 \pm 0.3 \mu \mathrm{mol} \cdot \mathrm{kg}^{-1}$ and the highest dose $\left(1000 \mu \mathrm{g} \cdot \mathrm{kg}^{-1}\right)$ produced a $67 \pm 4 \%$ reduction. The carotid haemodynamic effects of GMC2021 were reduced by the selective 5-HT 1 receptor antagonist, GR127935 ( $N$-[methoxy-3-(4-methyl-1piperazinyl)phenyl]-2'-methyl-4'-(5-methyl-1,2,4-oxadiazol-3-yl)[1,1-biphenyl]-4-carboxamide hydrochloride), which completely antagonizes porcine carotid haemodynamic responses to sumatriptan $\left(\mathrm{ED}_{50}: 0.16 \mu \mathrm{mol} \cdot \mathrm{kg}^{-1}\right.$, i.v. $)$. Compared to sumatriptan $\left(\mathrm{pD}_{2}\right.$ : $6.12 \pm 0.15 ; E_{\max }: 31.3 \pm 12.3 \%$ of contractions to $100 \mathrm{mM} \mathrm{K}^{+}$), GMC2021 was less potent in constricting the human isolated coronary artery $\left(\mathrm{pD}_{2}: 5.45 \pm 0.2 ; E_{\max }: 21.0 \pm 4.8 \%\right.$ of contractions to $\left.100 \mathrm{mM} \mathrm{K}^{+}\right)$. The above results suggest that GMC2021 constricts carotid arteriovenous anastomoses partly by a $5-\mathrm{HT}_{1 \mathrm{D}}$ receptor and partly by another, probably novel, receptor and that GMC2021 should be able to abort migraine headaches in patients, with perhaps a less propensity for coronary side effects.
\end{abstract}

Keywords: Antimigraine drug; Arteriovenous anastomosis; Carotid artery; GMC2021; Coronary artery, human; Migraine; Sumatriptan; (Human); (Pig)

\section{Introduction}

Recent progress in the field of migraine has led to the introduction of sumatriptan, the first of a completely new class of compounds, designated as 5 - $^{-T_{1}}$-like receptor agonists (for details, see Humphrey et al., 1990; Saxena and Ferrari, 1992). Sumatriptan, which effectively aborts migraine headaches (The Subcutaneous Sumatriptan International Study Group, 1991; Ferrari and Saxena, 1993), constricts large cranial and extracranial blood vessels (see

\footnotetext{
${ }^{*}$ Corresponding author. Tel.: $(+31)-(10)-408$ 7537/47; fax: $(+31)-$ (10)-436 6839; email: Saxena@Farma.Fgg.Eur.NL
}

Saxena and Tfelt-Hansen, 1993), including porcine carotid arteriovenous anastomoses (Den Boer et al., 1991a, 1992). The constriction of porcine arteriovenous anastomoses by sumatriptan is mediated via the 5- $\mathrm{HT}_{1}$-like receptor, because this effect is antagonized by methiothepin, but not by ketanserin (Saxena et al., 1986; Hoyer et al., 1994). Evidence is now emerging that this vascular $5-\mathrm{HT}_{1}$-like receptor may be identical to the recombinant $5-\mathrm{HT}_{1 \mathrm{D}}$, most probably $5-\mathrm{HT}_{1 \mathrm{D} \beta}$, receptor. Thus, the mRNA for the $5-\mathrm{HT}_{1 \mathrm{D} \beta}$, but not that for $5-\mathrm{HT}_{1 \mathrm{D} \alpha}$, receptor is present in cranial blood vessels (Hamel et al., 1993) and the vasoconstriction by sumatriptan, which has a high affinity for 5-HT 1 receptors (Peroutka and McCarthy, 1989; Beattie et al., 1994), is antagonized by GR127935, a selective 


\section{GMC2021}

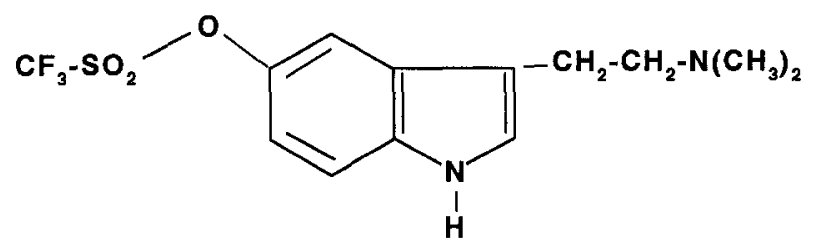

\section{Sumatriptan}

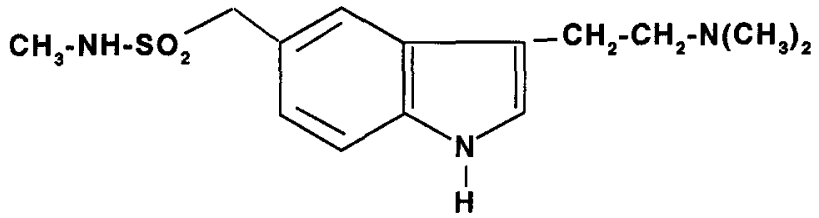

Fig. 1. Chemical structures of GMC2021 and sumatriptan.

5-HT $\mathrm{H}_{1 \mathrm{D}}$ receptor antagonist (Skingle et al., 1993; Clitherow et al., 1994; De Vries et al., 1996).

The success of sumatriptan in antimigraine therapy has prompted the synthesis and evaluation of new compounds with binding affinity and potential agonist activity at 5$\mathrm{HT}_{\text {ID }}$ receptors (for a review, see Saxena et al., 1996). One such compound, synthesized at the Department of Medicinal Chemistry, Faculty of Pharmacy, The State University, Groningen, Netherlands, is GMC2021, which is a close analogue of sumatriptan (Fig. 1). Like sumatrip$\tan , \mathrm{GMC} 2021$ shows selectivity for $5-\mathrm{HT}_{\mathrm{ID}}$ receptors; the $\mathrm{p} K_{\mathrm{i}}$ values of sumatriptan (Beattie et al., 1994) and GMC2021 (K. Svensson, unpublished observations) on cells transfected with human receptor clones are, respectively: $5-\mathrm{HT}_{1 \mathrm{~A}}, 7.00$ and $7.40 ; 5-\mathrm{HT}_{1 \mathrm{D \alpha}}, 8.50$ and 8.50 and $5-\mathrm{HT}_{1 \mathrm{D \beta}}, 8.10$ and 7.50. Furthermore, at $10 \mu \mathrm{M}$ GMC2021 inhibited forskolin-stimulated cAMP formation by $94 \%$ and $84 \%$, respectively, in cells with human $5-\mathrm{HT}_{1 \mathrm{D} \alpha}$ and $5-\mathrm{HT}_{1 \mathrm{D} \beta}$ receptors (K. Svensson, unpublished observations). In the present investigation, we have studied the effects of GMC2021 in experimental models predictive of therapeutic activity in migraine (constriction of carotid arteriovenous anastomoses in anaesthetized pigs; Saxena, 1990, 1995) and coronary side effects (constriction of human isolated coronary artery; Connor et al., 1989; Bax et al., 1993). In the latter model, sumatriptan was simultaneously used for a direct comparison, whereas data obtained in the first model were compared with that obtained with sumatriptan in a recent series of experiments ( $\mathrm{De}$ Vries et al., 1996).

\section{Materials and methods}

\subsection{Systemic and carotid haemodynamics in anaesthetized pigs}

\subsubsection{General}

After an overnight fast, 12 domestic pigs (Yorkshire $\times$ Landrace; $10-15 \mathrm{~kg}$ ) were anaesthetized with azaperone (160 mg, i.m.), midazolan hydrochloride (5 mg, i.m.) and metomidate ( $200 \mathrm{mg}$, i.v.), intubated and connected to a respirator (BEAR 2E, BeMeds AG, Baar, Switzerland) for intermittent positive pressure ventilation with a mixture of room air and oxygen. Respiratory rate, tidal volume and oxygen supply were adjusted to keep arterial blood gas values within physiological limits $\left(\mathrm{pH}: 7.35-7.48 ; \mathrm{pCO}_{2}\right.$ : $35-48 \mathrm{~mm} \mathrm{Hg} ; \mathrm{pO}_{2}: 100-120 \mathrm{~mm} \mathrm{Hg}$ ). Anaesthesia was maintained with a continuous i.v. infusion of pentobarbitone sodium at $20 \mathrm{mg} \cdot \mathrm{kg}^{-1} \cdot \mathrm{h}^{-1}$. With this anaesthetic regimen, arteriovenous anastomotic blood flow is considerably higher than that in pigs in a conscious state or under thiopentone anaesthesia (Den Boer et al., 1993).

Catheters were placed in the inferior vena cava via the left femoral vein for the administration of drugs and in the aortic arch via the left femoral artery for the measurement of arterial blood pressure (P23 Dc pressure transducer; Statham, Hato Rey, Puerto Rico) and the withdrawal of arterial blood for determining blood gases (ABL-510, Radiometer, Copenhagen, Denmark). The common carotid arteries, external jugular veins and vagus nerves were identified and both vagi and the accompanying cervical sympathetic nerves were cut between two ligatures. Another catheter was placed in the right external jugular vein for the withdrawal of venous blood samples, while the right common carotid artery was dissected free and a needle was inserted against the direction of blood flow for the administration and uniform mixing of radioactive microspheres. Blood flow was measured in the right common carotid artery with a flow probe (internal diameter: 2.5 $\mathrm{mm}$ ) connected to a sine-wave electromagnetic flow meter (Transflow 601-system, Skalar, Delft, Netherlands). Heart rate was measured with a tachograph (7P4 Grass Instrument Company, Quincy, Mass, USA) triggered by electrocardiogram signals.

Arterial blood pressure, heart rate and carotid blood flow were continuously monitored on a model 7 Grass polygraph. During the experiment body temperature was kept at about $37^{\circ} \mathrm{C}$ and the animals were continuously infused with saline to compensate for fluid losses.

\subsubsection{Distribution of carotid blood flow}

The distribution of common carotid blood flow was determined with $15 \pm 1$ (S.D.) $\mu \mathrm{m}$ diameter microspheres labelled with either ${ }^{141} \mathrm{Ce},{ }^{113} \mathrm{Sn},{ }^{95} \mathrm{Nb},{ }^{103} \mathrm{Ru}$ or ${ }^{46} \mathrm{Sc}$ (NEN Company, Dreieich, Germany). For each measure- 
ment a suspension of about 200000 microspheres, labelled with one of the isotopes, was mixed and injected into the carotid artery. At the end of the experiment, the animal was killed and the heart, kidneys, lungs and the different cranial tissues were dissected out, weighed and put in vials. The radioactivity in these vials was counted for 5-10 min in a $\gamma$-scintillation counter (Packard, Minaxi autogamma 5000), using suitable windows for discriminating the different isotopes. All data were processed by a set of specially designed programs (Saxena et al., 1980), using a personal computer.

The fraction of carotid blood flow distributed to the different tissues was calculated by multiplying the ratio of tissue and total radioactivities by the total common carotid blood flow at the time of the injection of microspheres. Since little or no radioactivity was detected in the heart and kidneys, all microspheres trapped in lungs reached this tissue from the venous side after escaping via carotid arteriovenous anastomoses. Therefore, the amount of radioactivity in the lungs was used as an index of the arteriovenous anastomotic fraction of carotid blood flow (Johnston and Saxena, 1978; Saxena and Verdouw, 1982).

\subsubsection{Experimental protocol}

The experiments were started after a stabilization period of about $1 \mathrm{~h}$. Thereafter, the animals were divided into two groups which received slow i.v. injections of either saline $(5 \mathrm{ml} ; n=6)$ or GR127935 $\left(0.5 \mathrm{mg} \cdot \mathrm{kg}^{-1} ; n=6\right)$ over a period of 3-4 min. After another $15 \mathrm{~min}$, baseline values of heart rate, mean arterial blood pressure, carotid blood flow and its distribution as well as arterial and jugular venous blood gases were measured. Subsequently, both groups of animals received cumulative i.v. doses of GMC2021 $\left(30,100,300\right.$ and $\left.1000 \mu \mathrm{g} \cdot \mathrm{kg}^{-1}\right)$ every 20 min. Fifteen minutes after each dose of GMC2021, all haemodynamic variables were assessed again.

\subsection{Human isolated coronary artery}

As described previously (Bax et al., 1993), the right epicardial coronary artery was obtained (via the Rotterdam Heart Valve Bank, Bio Implant Services/Eurotransplant Foundation) from 5 'heart beating' organ donors ( 3 males and 2 females between the ages of 4 and 52 years with mean \pm S.E.M. $35 \pm 8$ years), who died of cerebrovascular accident less than $24 \mathrm{~h}$ before the tissue was brought to the laboratory. Vessel segments containing macroscopically visible atherosclerotic lesions were excluded from the study and no attempt was made to denude endothelium.

Coronary artery segments (approximately $4 \mathrm{~mm}$ each) were suspended on stainless steel hooks in $15 \mathrm{ml}$ organ baths containing Krebs bicarbonate solution (composition in $\mathrm{mM}: \mathrm{NaCl} 118, \mathrm{KCl} 4.7, \mathrm{CaCl}_{2} 2.5, \mathrm{MgSO}_{4} 1.2$, $\mathrm{KH}_{2} \mathrm{PO}_{4}$ 1.2, $\mathrm{NaHCO}_{2} 25$ and glucose 8.3; pH 7.4), aerated with $95 \% \mathrm{O}_{2}$ and $5 \% \mathrm{CO}_{2}$ at $37^{\circ} \mathrm{C}$. They were allowed to equilibrate for at least $30 \mathrm{~min}$, with change of solution twice at a $15 \mathrm{~min}$ interval. Changes in tension were recorded with a Harvard isometric transducer. The vessel segments, stretched to a stable tension of about 15 $\mathrm{mN}$, were exposed to $30 \mathrm{mM} \mathrm{K}^{+}$twice. Subsequently, the functional integrity of the endothelium was verified by observing relaxation to substance $\mathrm{P}(1 \mathrm{nM})$ after precontraction with prostaglandin $\mathrm{F}_{2 \alpha}(1 \mu \mathrm{M})$. After washout, the tissue was exposed to $100 \mathrm{mM} \mathrm{K}^{+}$to determine the maximum contractile response to $\mathrm{K}^{+}$. After another 30 min equilibration period, a concentration response curve to either GMC2021 or sumatriptan ( $n=5$ each) was constructed. Contractile responses to GMC2021 and sumatrip-

Table 1

Absolute values of heart rate, mean arterial blood pressure and difference in arterial and jugular venous oxygen saturation at baseline and after cumulative doses of GMC2021 in animals pre-treated with either saline $(n=6)$ or GR127935 $\left(0.5 \mathrm{mg} \cdot \mathrm{kg}^{-1} ; n=6\right)$

\begin{tabular}{|c|c|c|c|c|c|}
\hline \multirow[t]{2}{*}{ Pretreatment } & \multicolumn{4}{|c|}{ GMC2021 $\left(\mu \mathrm{g} \cdot \mathrm{kg}^{-1}\right)$} & 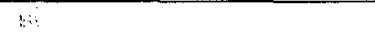 \\
\hline & Baseline & 30 & 100 & 300 & 1000 \\
\hline \multicolumn{6}{|c|}{ Heart rate (beats $\cdot \min ^{-1}$ ) } \\
\hline Saline & $94 \pm 2$ & $93 \pm 2(-1 \pm 0)$ & $91 \pm 2(-3 \pm 0)^{a}$ & $90 \pm 2(-4 \pm 1)^{a}$ & $89 \pm 2(-5 \pm 1)^{a}$ \\
\hline GR 127935 & $96 \pm 6$ & $95 \pm 6(-1 \pm 1)$ & $93 \pm 6(-3 \pm 1)^{a}$ & $92 \pm 6(-5 \pm 1)^{a}$ & $90 \pm 5(-7 \pm 1)^{a}$ \\
\hline \multicolumn{6}{|c|}{ Mean arterial blood pressure $(\mathrm{mm} \mathrm{Hg})$} \\
\hline Saline & $98 \pm 3$ & $94 \pm 4(-5 \pm 1)^{a}$ & $88 \pm 4(-11 \pm 1)^{a}$ & $79 \pm 3(-20 \pm 1)^{a}$ & $69 \pm 2(-30 \pm 1)^{2}$ \\
\hline GR 127935 & $102 \pm 6$ & $101 \pm 7(-1 \pm 2)$ & $99 \pm 8 \quad(-3 \pm 4)$ & $96 \pm 8(-6 \pm 4)^{b}$ & $91 \pm 8(-11 \pm 1)^{a, b}$ \\
\hline \multicolumn{6}{|c|}{ Arteriovenous difference in oxygen saturation (\%) } \\
\hline Saline & $10.1 \pm 1.5$ & $11.6 \pm 2.7(9 \pm 10)$ & $11.2 \pm 1.9(14 \pm 12)$ & $14.6 \pm 2.1 \quad(47 \pm 8)$ & $18.9 \pm 2.9(102 \pm 36)^{a}$ \\
\hline GR127935 & $5.4 \pm 1.4$ & $5.6 \pm 1.4(7 \pm 6)$ & $5.2 \pm 1.6(-8 \pm 10)$ & $5.2 \pm 1.6(-4 \pm 12)$ & $6.5 \pm 1.8 \quad(25 \pm 14)$ \\
\hline
\end{tabular}

Percentage changes from baseline in each variable is given in parentheses. All values have been presented as means \pm S.E.M. a $P<0.05$ vs. baseline;

${ }^{\mathrm{b}} P<0.05$ vs. corresponding dose in the saline-pre-treated group. 
$\tan$ were expressed as a percentage of the contraction induced by $100 \mathrm{mM} \mathrm{K} \mathrm{K}^{+}$.

\subsection{Ethical approval}

The protocols for the two parts of the investigation were approved by the joint Ethical Committees of the Erasmus University Rotterdam and the University Hospital Rotter-

GMC2021 ( $\left.\mu \mathrm{g} \cdot \mathrm{kg}^{-1}\right)$
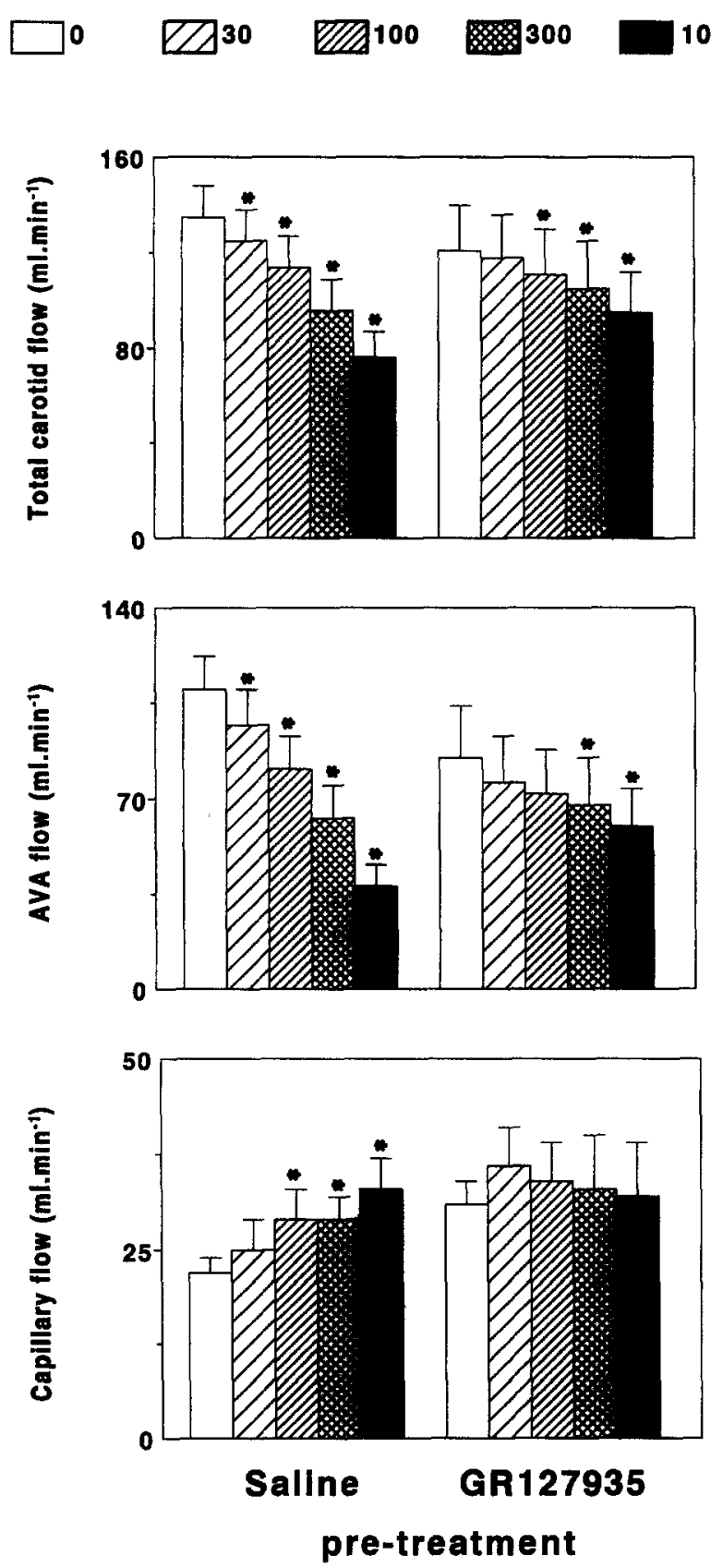

Fig. 2. Effect of GMC2021 (30-1000 $\left.\mu \mathrm{g} \cdot \mathrm{kg}^{-1}\right)$ on the total carotid blood flow and its arteriovenous anastomotic (AVA) and nutrient (capillary) fractions in anaesthetized pigs, pre-treated with either saline $(n=6)$ or GR127935 $\left(0.5 \mathrm{mg} \cdot \mathrm{kg}^{-1} ; n=6\right)$. All values are presented as means \pm S.E.M. ${ }^{*} P<0.05$ vs. baseline. dam 'Dijkzigt', dealing with the use of animals and humans in scientific experiments.

\subsection{Data presentation and statistical analysis}

All data have been expressed as means \pm S.E.M. The significance of the changes (from baseline values) induced by the different doses of GMC2021 was evaluated with Duncan's new multiple range test, once an analysis of variance (randomized block design) had revealed that the samples represented different populations. The changes caused by GMC2021 in saline- and GR127935-pre-treated groups at corresponding doses were compared by using a Student's $t$-test. Statistical significance was accepted at $P<0.05$ (two-tailed). In the saline-pre-treated group, the dose of GMC2021 eliciting a $50 \%$ decrease $\left(\mathrm{ED}_{50}\right)$ in arteriovenous anastomotic blood flow was calculated using linear regression analysis.

\subsection{Chemical compounds}

Apart from the anaesthetics, azaperone, metomidate (both from Janssen Pharmaceutica, Beerse, Belgium), midazolan hydrochloride (Hoffmann La Roche, Mijdrecht, Netherlands) and pentobarbitone sodium (Apharmo, Arnhem, Netherlands), the compounds used in this study were: prostaglandin $F_{2 \alpha}$ (Tris salt) and substance $P$ acetate (both purchased from Sigma Chemical Co., St. Louis, MO, USA); GMC2021 (3-[2-(dimethylanimo)ethyl]-5-[(trifluoromethyl)sulfonyl]oxy $[1 H]$ indole oxalate; Department of Medicinal Chemistry, University of Groningen, Netherlands), sumatriptan succinate, GR127935 ( $N$-[methoxy-3(4-methyl-1-piperazinyl)phenyl]-2'-methyl-4'-(5-methyl-1, 2,4-oxadiazol-3-yl)[1,1-bipheny1]-4-carboxamide hydrochloride (both gifted by Dr. Helen Connor, Glaxo Group Research, Ware, UK) and heparin sodium (Leo Pharmaceutical Products, Weesp, Netherlands) to prevent clotting of the catheters. GR127935 was solubilized according to the instructions of the manufacturer by heating the dispersion in distilled water to about $70^{\circ} \mathrm{C}$ and then allowing to cool down to room temperature. For in vitro experiments, all compounds (substance $\mathrm{P}$, prostaglandin $\mathrm{F}_{2 \alpha}$, sumatriptan and GMC2021) were dissolved in distilled water, while for in vivo experiments sumatriptan and GMC2021 were dissolved in physiological saline and all doses refer to the respective salts.

\section{Results}

\subsection{Systemic and carotid haemodynamics in anaesthetized pigs}

\subsubsection{Systemic haemodynamics}

As shown in Table 1, in the saline-pre-treated animals GMC2021 elicited a slight decrease in heart rate (maximum change: $-5 \pm 1 \%$ ), but arterial blood pressure decreased more substantially (maximum decrease: $30 \pm 1 \%$ ). 
Saline pre-treated

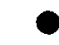

Total carotid
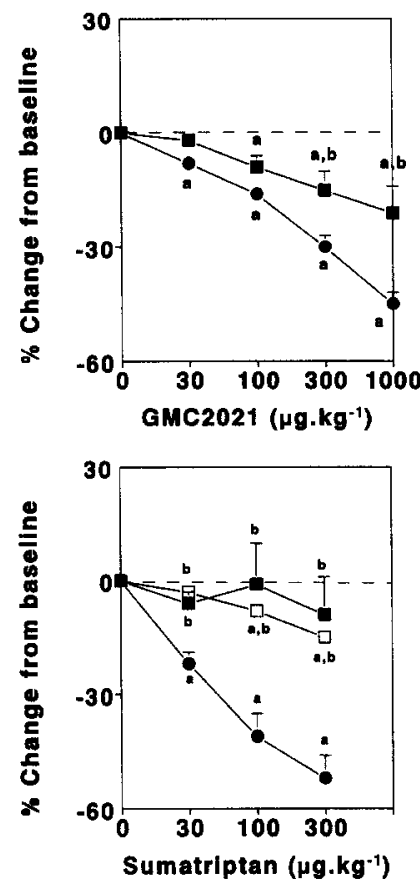

GR127935 pre-treated

\section{$0.25 \mathrm{mg} \cdot \mathrm{kg}^{-1}$}

AVA
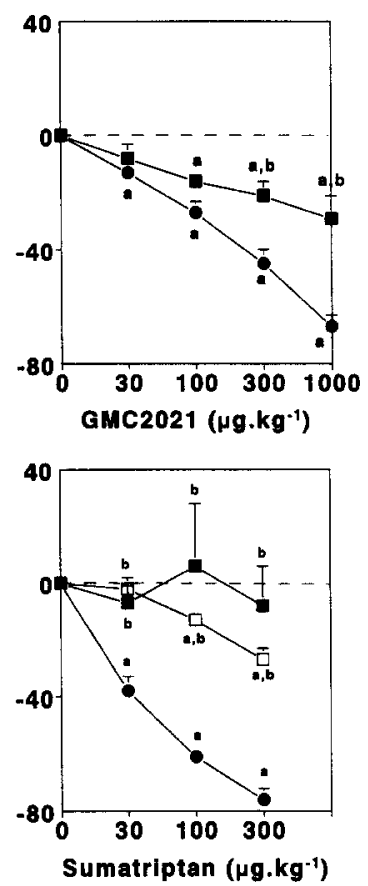

$0.5 \mathrm{mg} \cdot \mathrm{kg}^{-1}$

Capillary
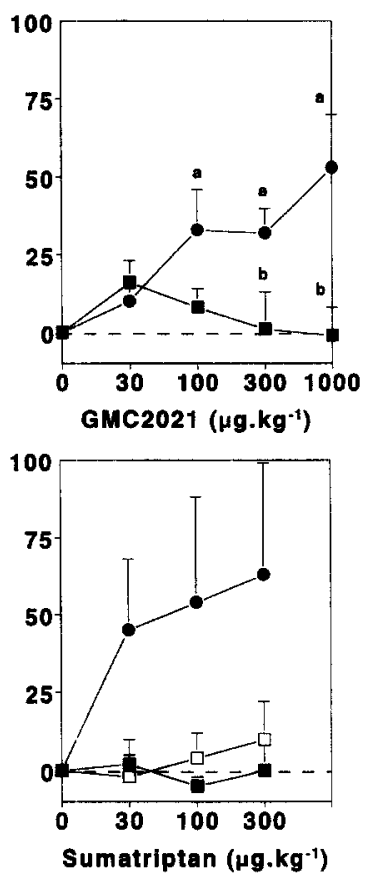

Fig. 3. Percent changes from baseline values by GMC2021 $\left(30-1000 \mu \mathrm{g} \cdot \mathrm{kg}^{-1}\right.$; upper panels) in the total carotid blood flow and its arteriovenous anastomotic (AVA) and nutrient (capillary) fractions in anaesthetized pigs, pre-treated with either saline $(n=6)$ or $\mathrm{GR} 127935\left(0.5 \mathrm{mg} \cdot \mathrm{kg}^{-1} ; n=6\right)$. Data recently obtained in similar experiments with sumatriptan (De Vries et al., 1996; lower panels; $n=4-5$ ) are presented for comparison. All values are presented as means \pm S.E.M. ${ }^{a} P<0.05$ vs. baseline; ${ }^{b} P<0.05$ vs. corresponding change in the saline-pre-treated group.

While pre-treatment of the animals with GR127935 $(0.5$ $\mathrm{mg} \cdot \mathrm{kg}^{-1}$ ) did not modify the effect of GMC2021 on heart rate, the effect on arterial blood pressure was significantly reduced (Table 1).

\subsubsection{Arterio-jugular venous oxygen saturation difference}

In the saline-pre-treated group, the arterio-jugular venous oxygen saturation difference increased significantly after the highest dose $\left(1000 \mu \mathrm{g} \cdot \mathrm{kg}^{-1}\right)$ of GMC2021.

Table 2

Absolute values ( $\mathrm{mm} \mathrm{Hg} \cdot \mathrm{ml}^{-1} \cdot \mathrm{min}^{-1}$ ) of total carotid vascular resistance and its fractionation into arteriovenous anastomotic and capillary (nutrient) parts at baseline and after cumulative doses of GMC2021 in animals pre-treated with either saline $(n=6)$ or GR127935 $\left(0.5 \mathrm{mg} \cdot \mathrm{kg}^{-1} ; n=6\right)$

\begin{tabular}{|c|c|c|c|c|c|}
\hline \multirow[t]{2}{*}{ Pretreatment } & \multicolumn{5}{|c|}{ GMC2021 $\left(\mu \mathrm{g} \cdot \mathrm{kg}^{-1}\right)$} \\
\hline & Baseline & 30 & 100 & 300 & 1000 \\
\hline \multicolumn{6}{|c|}{ Total carotid resistance } \\
\hline GR 127935 & $0.98 \pm 0.19$ & $0.97 \pm 0.17(1 \pm 3)$ & $1.06 \pm 0.22(7 \pm 8)$ & $1.13 \pm 0.28(13 \pm 13)$ & $1.15 \pm 0.29(19 \pm 16)$ \\
\hline \multicolumn{6}{|c|}{ Arteriovenous anastomotic resistance } \\
\hline Saline & $0.95 \pm 0.10$ & $1.04 \pm 0.12(10 \pm 6)$ & $1.18 \pm 0.14(24 \pm 6)^{a}$ & $1.45 \pm 0.22(51 \pm 15)^{a}$ & $2.19 \pm 0.37(125 \pm 26)^{a}$ \\
\hline \multicolumn{6}{|c|}{ Capillary (nutrient) resistance } \\
\hline Saline & $4.85 \pm 0.66$ & $4.43 \pm 0.80(-12 \pm 6)$ & $3.35 \pm 0.54(-31 \pm 5)^{a}$ & $3.03 \pm 0.55(-39 \pm 4)^{\mathrm{a}}$ & $2.30 \pm 0.38(-52 \pm 5)^{\mathrm{a}}$ \\
\hline GR127935 & $3.46 \pm 0.40$ & $2.99 \pm 0.37 \quad(13 \pm 5)$ & $3.24 \pm 0.55(-9 \pm 8)^{b}$ & $3.75 \pm 0.94 \quad(1 \pm 16)^{b}$ & $3.53 \pm 0.85(-4 \pm 14)^{b}$ \\
\hline
\end{tabular}

Percentage changes from baseline in each variable is given in parentheses. All values have been presented as means \pm S.E.M. ${ }^{a} P<0.05$ vs. baseline; ${ }^{\mathrm{b}} P<0.05$ vs. corresponding dose in the saline-pre-treated group. 
Pre-treatment with GR127935 antagonized the effect of GMC2021 (Table 1).

\subsubsection{Carotid haemodynamics}

As shown in Fig. 2 (absolute values) and Fig. 3 (upper panels; percentage change from baseline values), GMC2021 (30, 100, 300 and $1000 \mu \mathrm{g} \mathrm{kg}^{-1}$, i.v. ) elicited a dose-dependent decrease in both the total carotid and arteriovenous anastomotic blood flows, but the total capillary fraction was increased. The $\mathrm{ED}_{50}$ of $\mathrm{GMC}_{2021}$ in decreasing arteriovenous anastomotic blood flow in the 6 saline-pre-treated animals was found to be $467 \pm 128 \mu \mathrm{g}$. $\mathrm{kg}^{-1}\left(1.1 \pm 0.3 \mu \mathrm{mol} \cdot \mathrm{kg}^{-1}\right)$ and with the highest dose $\left(1000 \mu \mathrm{g} \cdot \mathrm{kg}^{-1}\right)$ the decrease amounted to be $67 \pm 4 \%$. In animals pre-treated with GR $127935\left(0.5 \mathrm{mg} \cdot \mathrm{kg}^{-1}\right)$, where the baseline values of arteriovenous anastomotic blood flow were less than in saline-pre-treated animals due to its partial agonist action (see De Vries et al., 1996), the GMC2021-induced decreases in the total carotid blood flow and its arteriovenous anastomotic fraction were reduced (the decrease in arteriovenous anastomotic blood flow by the highest dose was $29 \pm 8 \%$ ) and the GMC2021-induced increase in the capillary blood flow was completely blocked (see Fig. 3; upper panels). In similar recent experiments, sumatriptan decreased the total carotid and arteriovenous anastomotic blood flows, but the increase in the capillary blood flow was not statistically significant (De Vries et al., 1996). The $\mathrm{ED}_{50}$ of sumatriptan in decreasing arteriovenous anastomotic blood flow was $63 \pm 17 \mu \mathrm{g} \cdot \mathrm{kg}^{-1}\left(0.16 \pm 0.04 \mu \mathrm{mol} \cdot \mathrm{kg}^{-1}\right)$ and the
Pre-treatment: Saline

GR127935 (0.5 mg.kg-1)
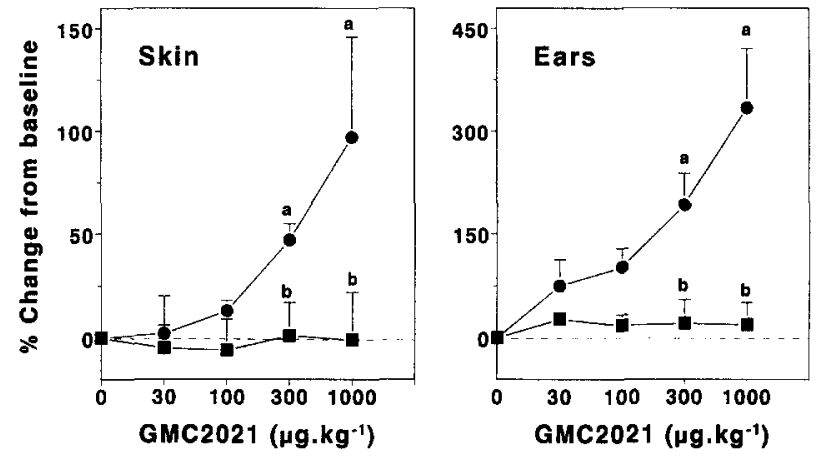

Fig. 5. Effect of GMC2021 $\left(30-1000 \mu \mathrm{g} \cdot \mathrm{kg}^{-1}\right)$ on the distribution of carotid blood flow to skin and ears in anaesthetized pigs, pre-treated with either saline $(n=6)$ or GR127935 $\left(0.5 \mathrm{mg} \cdot \mathrm{kg}^{-1} ; n=6\right)$. All values are presented as means \pm S.E.M. ${ }^{a} P<0.05$ vs. baseline; ${ }^{b} P<0.05$ vs. corresponding change in the saline-pre-treated group.

highest dose used $\left(300 \mu \mathrm{g} \cdot \mathrm{kg}^{-1}\right)$ decreased arteriovenous anastomotic blood flow by $76 \pm 4 \%$. In animals pretreated with GR127935, the effects of sumatriptan were substantially reduced $\left(0.25 \mathrm{mg} \cdot \mathrm{kg}^{-1}\right)$ or completely blocked $(0.5$ $\left.\mathrm{mg} \cdot \mathrm{kg}^{-1}\right)$ (De Vries et al., 1996; Fig. 3, lower panels).

The effects of GMC2021 on the total carotid vascular resistance and its fractionation into arteriovenous and capillary parts are shown in Table 2. GMC2021 increased the total carotid and, particularly, the arteriovenous anastomotic resistance, but decreased the capillary resistance. The effects of GMC2021 were much reduced (total carotid

GMC2021 ( $\mu \mathrm{g} \cdot \mathrm{kg}^{-1}$ )

$\square 0 \quad \square 30 \quad \square 100 \quad 300 \quad 1000$
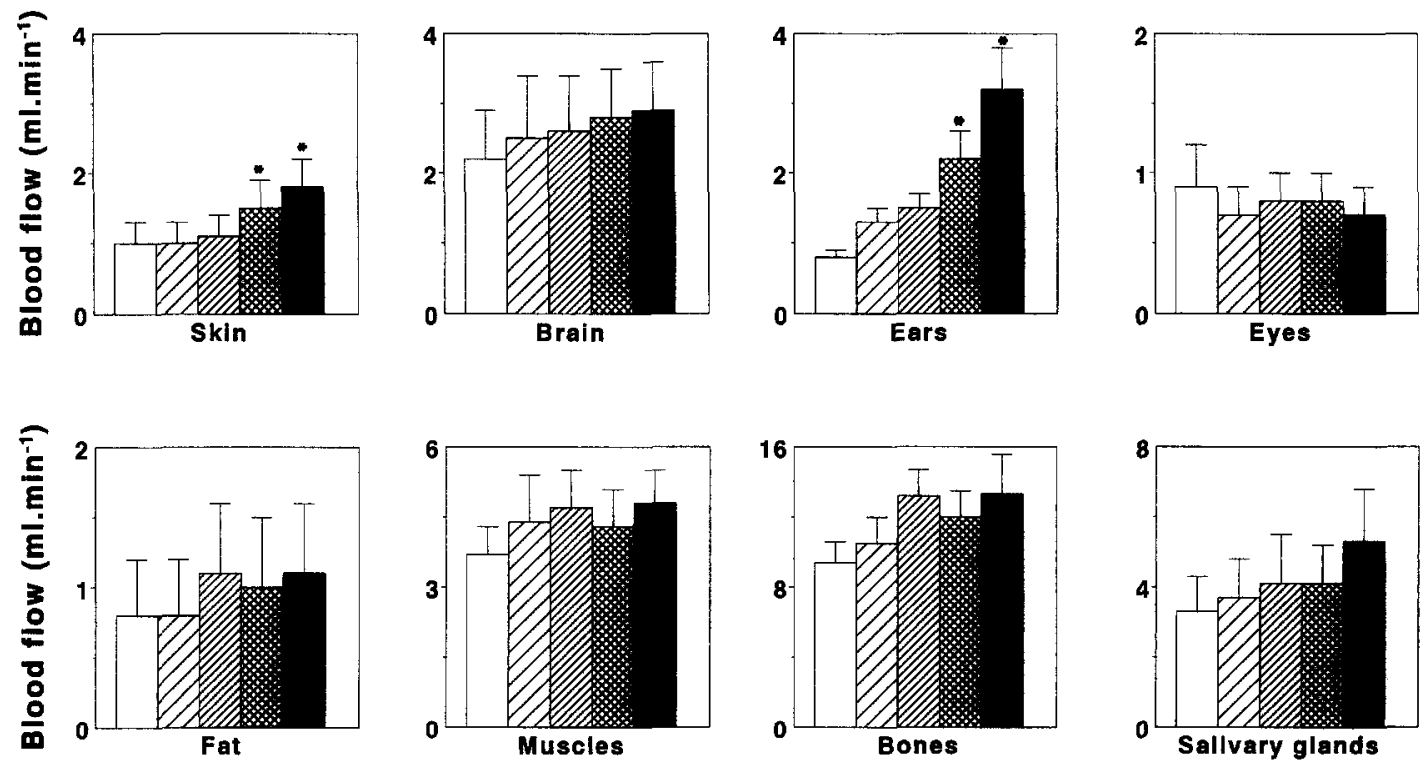

Fig. 4. Effect of GMC2021 (30-1000 $\left.\mu \mathrm{g} \cdot \mathrm{kg}^{-1}\right)$ on the distribution of carotid blood flow to different cranial tissues in anaesthetized pigs, pre-treated with saline $(n=6)$. All values are presented as means \pm S.E.M. ${ }^{*} P<0.05$ vs. baseline. 


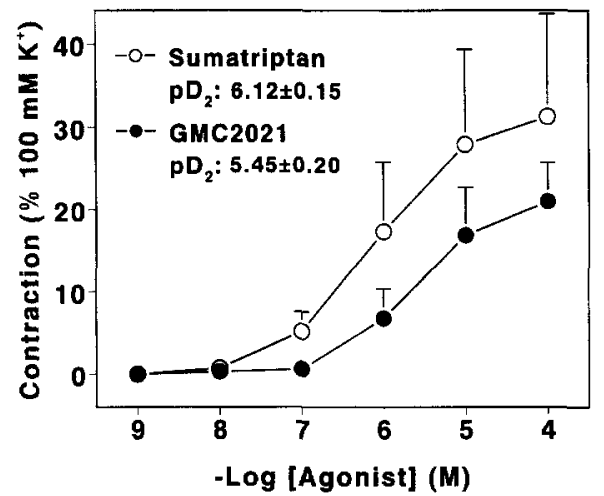

Fig. 6. Human isolated coronary artery. Contractile responses to GMC2021 $(n=6)$ and sumatriptan $(n=6)$, both expressed as percentage of the response to $100 \mathrm{mM} \mathrm{K}^{+}$.

and its arteriovenous anastomotic fraction) or completely blocked (capillary resistance) in animals pre-treated with GR127935.

The distribution of carotid blood flow to the head tissues in the saline-pre-treated animals is depicted in Fig. 4. GMC2021 did not significantly modify the fraction of carotid blood flow distributed to the brain, eyes, fat, muscles, bones or salivary glands, but skin and ear fractions increased significantly. The increase in skin and ears with the highest dose of GMC2021 were $97 \pm 49 \%$ and $334 \pm 87 \%$, respectively and these effects were completely antagonized in animals pre-treated with GR127935 (Fig. 5).

\subsection{Human isolated coronary artery}

\subsubsection{Effect of substance $P$ and $K^{+}$}

Coronary vessel segments relaxed to substance $P$ (1 $n M)$ after precontraction with prostaglandin $F_{2 \alpha}(1 \mu \mathrm{M})$ by $63 \pm 18 \%$ of the contractile responses to prostaglandin $\mathrm{F}_{2 \alpha} \cdot \mathrm{K}^{+}(100 \mathrm{mM})$ caused a mean contractile response of $33.7 \pm 5.6 \mathrm{mN}$.

\subsubsection{Effect of sumatriptan and GMC2021}

As shown in Fig. 6, the human isolated coronary artery contracted to sumatriptan $\left(\mathrm{pD}_{2}: 6.12 \pm 0.15 ; E_{\max }: 31.3 \pm\right.$ $12.3 \%$ of contractions to $100 \mathrm{mM} \mathrm{K}^{+}$) more potently than to GMC2021 $\left(\mathrm{pD}_{2}: 5.45 \pm 0.20 ; E_{\max }: 21.0 \pm 4.8 \%\right.$ of contractions to $100 \mathrm{mM} \mathrm{K}^{+}$).

\section{Discussion}

\subsection{Systemic haemodynamic changes}

GMC2021 produced small decreases in heart rate $(5 \pm$ $1 \%$ after the highest dose of $1000 \mu \mathrm{g} \cdot \mathrm{kg}^{-1}$ ), both in saline- and GR127935-pre-treated animals. While it is recognized that this small change may not be drug-related, it has to be pointed out that a similar bradycardic effect has often been reported with sumatriptan (Feniuk et al., 1989; Den Boer et al., 1991a, 1992; De Vries et al., 1996); in similar experiments no changes in heart rate occurred after four consecutive bolus injections of saline (Den Boer et al., 1991a). The mechanism involved in the rather small decrease in heart rate by sumatriptan (or GMC2021) is not clear, but may be related to presynaptic inhibition of sympathetic neurons (Humphrey et al., 1988, 1990) or central 5- $\mathrm{HT}_{1 \mathrm{~A}}$ receptor activation (Dreteler et al., 1989; Saxena and Villalón, 1990). However, in any case, bradycardia following the use of sumatriptan in patients seems to be of little clinical relevance (Saxena and Tfelt-Hansen, 1993).

In contrast to sumatriptan (Den Boer et al., 1991a), GMC2021 produced a decrease in arterial blood pressure. This effect of GMC2021 was reduced in animals pre-treated with GR127935, implying a novel 5-HT 1 receptor-mediated mechanism, perhaps within the central nervous system. GMC2021 seems to enter the brain as suggested by hypothermia $\left( \pm 2^{\circ} \mathrm{C}\right)$ in the guinea-pig observed with this compound, but not with sumatriptan (K. Svensson, unpublished observations). Since the hypotensive effect of GMC2021 was not completely blocked in GR127935-pretreated animals, a part of the action may be due to an agonist action on central 5- $\mathrm{HT}_{1 \mathrm{~A}}$ receptors; GMC2021 has a substantial affinity for $5-\mathrm{HT}_{1 \mathrm{~A}}$ receptors $\left(\mathrm{p} K_{\mathrm{i}}: 7.40 ; \mathrm{K}\right.$. Svensson, unpublished observations).

\subsection{Carotid haemodynamic changes}

GMC2021 $\left(30,100,300\right.$ and $\left.1000 \mu \mathrm{g} \cdot \mathrm{kg}^{-1}\right)$ elicited a dose-dependent reduction in the total carotid blood flow, which was exclusively due to a decrease in its arteriovenous anastomotic fraction; the arterio-jugular venous oxygen saturation difference, however, increased significantly only with the highest dose. The effects of GMC2021 were qualitatively similar to, but less than those observed with sumatriptan in the same experimental model (Fig. 3; see also Den Boer et al., 1991a; De Vries et al., 1996). The $\mathrm{ED}_{50}$ of GMC2021 and sumatriptan in decreasing arteriovenous anastomotic blood flow were, respectively, $1.1 \pm$ $0.3 \mu \mathrm{mol} \cdot \mathrm{kg}^{-1}$ (present experiments) and $0.16 \pm 0.04$ $\mu \mathrm{mol} \cdot \mathrm{kg}^{-1}$ (De Vries et al., 1996). However, in contrast to sumatriptan-induced reductions in the total and arteriovenous anastomotic blood flows, which were completely abolished by $0.5 \mathrm{mg} \cdot \mathrm{kg}^{-1}$ GR 127935 (De Vries et al., 1996), the effects of GMC2021 were only partially blocked (see Fig. 3). The partial blockade of the vasoconstrictor effect of GMC2021 cannot be explained by the decrease in the baseline value (see Table 2), due to the agonist action of GR127935 (Pauwels and Colpaert, 1995; Watson et al., 1995; De Vries et al., 1996). While this decrease in the baseline will tend to exaggerate the effects of GMC2021 expressed as percentage change from baseline, the effect expressed in absolute values (i.e. $\mathrm{ml} \cdot \mathrm{min}^{-1}$ ) may in fact appear masked. Moreover, in the face of a similar agonist 
action, GR127935 $\left(0.5 \mathrm{mg} \cdot \mathrm{kg}^{-1}\right)$ did completely block the responses to sumatriptan, which was more potent than GMC2021.

Taking into account that sumatriptan (Peroutka and McCarthy, 1989; Schoeffter and Hoyer, 1989; Beattie et al., 1994), GMC2021 (K. Svensson, unpublished observations) as well as GR127935 (Clitherow et al., 1994; Skingle et al., 1993; Pauwels and Colpaert, 1995; Watson et al., 1995) have high affinities for $5-\mathrm{HT}_{1 \mathrm{D}}$ receptors, our results suggest that the GMC2021-induced constriction of carotid arteriovenous anastomoses is partly mediated by $5-\mathrm{HT}_{1 \mathrm{D}}$ receptors, reinforcing the view that $5-\mathrm{HT}_{1}$-like and $5-\mathrm{HT}_{1 \mathrm{D}}$ receptors may be identical. Although none of these compounds distinguish between $5-\mathrm{HT}_{1 \mathrm{D} \alpha}$ and $5-\mathrm{HT}_{1 \mathrm{D} \beta}$ subtypes, the presence of the 5-HT $1 \mathrm{D \beta} m \mathrm{RNA}$, but not $5-\mathrm{HT}_{1 \mathrm{D} \alpha}$ receptor $m \mathrm{RNA}$, in human and bovine cerebral arteries (Hamel et al., 1993) indicates that the $5-\mathrm{HT}_{1 \mathrm{D} \beta}$ receptor mediates contractile responses in cranial vessels.

The lack of complete blockade of GMC2021-induced porcine carotid arteriovenous anastomotic contraction by GR127935 may imply that, apart from a 5- $\mathrm{HT}_{1 \mathrm{D}}$ receptor, another receptor is involved in this effect of GMC2021. Although the nature of this receptor is not known, it is interesting to recall that, unlike 5-HT or sumatriptan, the effects of ergotamine and dihydroergotamine on porcine arteriovenous anastomoses are also only partially blocked by the $5-\mathrm{HT}_{1}$ and $5-\mathrm{HT}_{2}$ receptor antagonist, methiothepin (Saxena et al., 1986; Den Boer et al., 1991b). If, indeed, a novel receptor mediates the contraction of carotid arteriovenous anastomoses, it would obviously provide another avenue for drug development against migraine.

As reported earlier from our laboratory with sumatrip$\tan$ (Den Boer et al., 1991a; De Vries et al., 1996), GMC2021 conspicuously increased blood flows to the skin and ears. Although these increases were not observed in animals pre-treated with GR127935, it may be argued that the dilatation of the skin and ear arterioles is an indirect consequence of the closure of arteriovenous anastomoses by GMC2021. On the other hand, Schoeffter and Hoyer (1990) have reported 5-HT receptors similar to the 5-HT receptor subtype mediate endothelium-dependent relaxations of porcine isolated coronary artery.

\subsection{Human isolated coronary artery}

GMC2021 contracted the human isolated coronary artery with a $\mathrm{pD}_{2}$ of 5.45 and $E_{\max }$ of $21.0 \%$ of contractions to $100 \mathrm{mM} \mathrm{K}^{+}$. This effect was lower than that of sumatrip$\tan \left(\mathrm{pD}_{2}: 6.12 ; E_{\max }: 31.3 \%\right.$ of contractions to $100 \mathrm{mM}$ $\mathrm{K}^{+}$). It is known that the effects of sumatriptan on the human isolated coronary artery are mediated by a $5-\mathrm{HT}_{1}$ like receptor (Connor et al., 1989; Bax et al., 1993), which may resemble the 5- $\mathrm{HT}_{1 \mathrm{D} \beta}$ receptor subtype (Kaumann et al., 1994). In view of the lower $\mathrm{pD}_{2}$ on coronary vessels as well as lower $\mathrm{p} K_{\mathrm{i}}$ value at the $5-\mathrm{HT}_{1 \mathrm{D \beta}}$ receptor of GMC2021 than the corresponding values for sumatriptan, it would seem that a 5- $\mathrm{HT}_{1 \mathrm{D} \beta}$-like receptor is also involved in the coronary vascular effects of GMC2021.

\subsection{Clinical perspectives}

Over the years it has been shown that a number of drugs effective in aborting migraine headaches, including the ergot alkaloids, ergotamine and dihydroergotamine (Johnston and Saxena, 1978; Schamhardt et al., 1979; Spierings and Saxena, 1980; Den Boer et al., 1991b), sumatriptan (Den Boer et al., 1991a) as well as several second generation 5- $\mathrm{HT}_{1 \mathrm{D}}$ receptor agonists undergoing clinical evaluation in migraine (e.g., zolmitriptan, BMS180048 and MK-462; Boulanger et al., 1995; Martin and Dixon, 1995; Saxena et al., 1996), are able to constrict carotid arteriovenous anastomoses, which may open up during the headache phase of migraine (see Heyck, 1969; Saxena, 1990, 1995; Ferrari and Saxena, 1993). It has recently also been found that sumatriptan can constrict dilated arteriovenous anastomoses in the human forearm (Van Es et al., 1995). Since GMC2021 constricted carotid arteriovenous anastomoses, we believe that this drug should also be able to abort migraine headaches in patients. The drug was pharmacodynamically less potent than sumatrip$\tan$, both in the experimental model predictive of therapeutic efficacy in migraine and in the model indicative of potential coronary side effects; the efficacy of GMC2021 and sumatriptan in decreasing porcine arteriovenous anastomotic blood flow were almost equal $(67 \pm 4$ and $76 \pm 4 \%$ by 1000 and $300 \mu \mathrm{g} \cdot \mathrm{kg}^{-1}$, respectively). However, a potential disadvantage of GMC2021 may be its hypotensive action, if also observed during clinical usage.

Further pharmacokinetic evaluation, particularly concerning the duration of action and the extent of oral absorbtion, two of the short-comings of sumatriptan (see Ferrari and Saxena, 1993; Saxena and Tfelt-Hansen, 1993), will dictate the future development of GMC2021. However, on the basis of experience with other triflated analogues, for example tetralin-based dopamine and serotonin receptor ligands (Sonesson et al., 1993, 1995), it may be expected that GMC2021 should have a good oral bioavailability and duration of action. Indeed, this last possibility is suggested by our preliminary observations that a single i.v. dose of GMC2021 elicited a biphasic reduction in porcine carotid blood flow (initial effect for 5-10 min followed by a later effect between 60 and $120 \mathrm{~min}$ ).

In conclusion, the results of the present experiments show that GMC2021, a close analogue of sumatriptan, causes constriction of porcine carotid arteriovenous anastomoses (suggestive of therapeutic activity in migraine) and the human isolated coronary artery (possibly indicative of coronary side-effects). The constriction of arteriovenous anastomoses seems to involve a $5-\mathrm{HT}_{1 \mathrm{D}}$ receptors, but possibly also a novel receptor which could provide a new avenue for developing antimigraine drugs. 


\section{Acknowledgements}

This study was partially supported by the Netherlands Heart Foundation, grant No. 93.146.

\section{References}

Bax, W.A., G.J. Renzenbrink, D. Van Heuven-Nolsen, E.J.M. Thijssen, E. Bos and P.R. Saxena, 1993, 5-HT receptors mediating contractions of the isolated human coronary artery, Eur. J. Pharmacol. 239, 203.

Beattie, D.T., H.E. Connor, W. Feniuk and P.P.A. Humphrey, 1994, The pharmacology of sumatriptan, Rev. Contemp. Pharmacother. 5, 285.

Boulanger, C.M., J. Longmore, B. Desta and W. Schofield, 1995, Further studies on the response of human coronary arteries to the $5-\mathrm{HT}_{1 \mathrm{D}}$ receptor agonists sumatriptan and MK-462, Br. J. Pharmacol. 116, $38 \mathrm{P}$.

Clitherow, J.W., D.I. Scopes, M. Skingle, C.C. Jordan, W. Feniuk, I.B. Campbell, M.C. Carter, E.W. Collington, H.E. Connor, G.A. Higgins, D. Beattie, H.A. Kelly, W.L. Mitchell, A.W. Oxford, A.H. Wadsworth and M.B. Tyers, 1994, Evolution of a novel series of [ $N, N$-dimethylamino) propyl- and piperazinylbenzanilides as the first selective 5- $\mathrm{HT}_{1 \mathrm{D}}$ antagonists, J. Med. Chem. 37, 2253.

Connor, H.E., W. Feniuk and P.P.A. Humphrey, 1989, 5-Hydroxytryptamine contracts human coronary arteries predominantly via $5-\mathrm{HT}_{2}$ receptor activation, Eur. J. Pharmacol. 161, 91.

Den Boer, M.O., C.M. Villalón, J.P.C. Heiligers, P.P.A. Humphrey and P.R. Saxena, 1991a, Role of 5-HT, -like receptors in the reduction of porcine cranial arteriovenous anastomotic shunting by sumatriptan, Br. J. Pharmacol. 102, 323.

Den Boer, M.O., J.P.C. Heiligers and P.R. Saxena, 1991b, Carotid vascular effects of ergotamine and dihydroergotamine in the pig: no exclusive mediation via 5-HT 1 -like receptors, Br. J. Pharmacol. 104, 183.

Den Boer, M.O., C.M. Villalón and P.R. Saxena, 1992, 5-HT,-like receptors mediated changes in porcine carotid haemodynamics: are $5-\mathrm{HT}_{1 \mathrm{D}}$-receptors involved?, Naunyn-Schmiedeberg's Arch. Pharmacol. 345, 509.

Den Boer, M.O., L.J. Van Woerkens, J.A.E. Somers, D.J. Duncker, B. Lachmann, P.R. Saxena and P.D. Verdouw, 1993, On the preservation and regulation of vascular tone in arteriovenous anastomoses during anesthesia, J. Appl. Physiol. 75, 782 .

De Vries, P., J.P.C. Heiligers, C.M. Villalón and P.R. Saxena, 1996 Blockade of porcine carotid vascular responses to sumatriptan by GR127935, a selective 5-HT 1 receptor antagonist, Br. J. Pharmacol. 118,85 .

Dreteler, G.H., W. Wouters and P.R. Saxena, 1989, Systemic and regional haemodynamic effects of the putative $5-\mathrm{HT}_{1 \mathrm{~A}}$ receptor agonist flesinoxan in the cat, J. Cardiovasc. Pharmacol. 14, 770.

Feniuk, W., P.P.A. Humphrey and M.J. Perren, 1989, The selective carotid arterial vasoconstrictor action of GR43175 in anaesthetized dogs, Br. J. Pharmacol. 96, 83.

Ferrari, M.D. and P.R. Saxena, 1993, Clinical and experimental effects of sumatriptan in humans, Trends Pharmacol. Sci. 14, 129.

Hamel, E., E. Fan. D. Linville, V. Ting, J.-G. Villemure and L.-S. Chia, 1993, Expression of mRNA for serotonin 5-hydroxytryptamine ${ }_{\text {ID }}$ receptor subtype in human and bovine cerebral arteries, Mol. Pharmacol. $44,242$.

Heyck, H., 1969, Pathogenesis of migraine, Res. Clin. Stud. Headache 2, 1.

Hoyer, D., D.E. Clarke, J.R. Fozard, P.R. Hartig, G.R. Martin, E.J. Mylecharane, P.R. Saxena and P.P.A. Humphrey, 1994, International Union of Pharmacology classification of receptors for 5-hydroxytryptamine (serotonin), Pharmacol. Rev. 46, 157

Humphrey, P.P.A., W. Feniuk, M.J. Perren, H.E. Connor, A.W. Oxford,
I.H. Coates and D. Butina, 1988, GR43175, a selective agonist for the 5- $\mathrm{HT}_{1}$-like receptor in dog isolated saphenous vein, $\mathrm{Br}$. J. Pharmacol. 94, 1123.

Humphrey, P.P.A., E. Apperley, W. Feniuk and M.J. Perren, 1990, A rational approach to identifying a fundamentally new drug for the treatment of migraine, in: Cardiovascular Pharmacology of 5-Hydroxytryptamine: Prospective Therapeutic Applications, ed. P.R. Saxena, D.I. Wallis, W. Wouters and P. Bevan (Kluwer Academic Publishers, Dordrecht) p. 416.

Johnston, B.M. and P.R. Saxena, 1978, The effect of ergotamine on tissue blood flow and the arteriovenous shunting of radioactive microspheres in the head, Br. J. Pharmacol. 63, 541.

Kaumann, A.J., M. Frenken, H. Posival and A.M. Brown, 1994, Variable participation of 5- $\mathrm{HT}_{1}$-like receptors and 5- $\mathrm{HT}_{2}$ receptors in serotonin-induced contraction of human isolated coronary arteries; 5$\mathrm{HT}_{1}$-like receptors resemble cloned $5-\mathrm{HT}_{1 \mathrm{D} \beta}$ receptors, Circulation 90,1141 .

Martin, G.R. and R. Dixon, 1995, Pre-clinical and clinical pharmacology of the novel antimigraine compound 311C90, Poster, American Association for the Study of Headache, Toronto.

Pauwels, P.J. and F.C. Colpaert, 1995, The 5-HT $\mathrm{HD}_{1 \mathrm{D}}$ receptor antagonist GR 127935 is an agonist at cloned human $5-\mathrm{HT}_{\mathrm{ID} \alpha}$ receptor sites, Neuropharmacology 34, 235.

Peroutka, S.J. and B.G. McCarthy, 1989, Sumatriptan (GR 43175) interacts selectively with $5-\mathrm{HT}_{1 \mathrm{~B}}$ and $5-\mathrm{HT}_{\mathrm{ID}}$ binding sites, Eur. J. Pharmacol. 163, 133.

Saxena, P.R., 1990, Is there still a case for the shunt hypothesis in migraine?, in: Migraine: A Spectrum of Ideas, ed. M. Sandler and G.M. Collins (Oxford University Press, Oxford) p. 191.

Saxena, P.R., 1995, Cranial arteriovenous shunting: an in vivo animal model for migraine, in: Experimental Headache Models in Animal and Man, eds. J. Olesen and M.A. Moskowitz (Lippincott-Raven Publishers, Philadelphia) p. 189.

Saxena, P.R. and M.D. Ferrari, 1992, From serotonin receptor classification to the antimigraine drug sumatriptan, Cephalalgia 12,187

Saxena, P.R. and P. Tfelt-Hansen, 1993, Sumatriptan, in: The Headaches, eds. J. Olesen, P. Tfelt-Hansen and K.M.A. Welch (Raven Press Ltd., New York) p. 329.

Saxena, P.R. and P.D. Verdouw, 1982, Redistribution by 5-HT on carotid arterial blood at the expense of arteriovenous blood flow, J. Physiol. (London) 332, 501.

Saxena, P.R. and C.M. Villalón, 1990, Cardiovascular effects of serotonin agonists and antagonists, J. Cardiovasc. Pharmacol. 15 (Suppl. 7), S17.

Saxena, P.R., H.C. Schamhardt, R.P. Forsyth and J. Loeve, 1980, Computer programs for the radioactive microsphere technique. Determination of regional blood flows and other haemodynamic variables in different experimental circumstances, Comp. Progr. Biomed. 12, 63.

Saxena, P.R., D.J. Duncker, A.H. Bom, J. Heiligers and P.D. Verdouw, 1986, Effects of MDL 72222 and methiothepin on carotid vascular responses to 5-hydroxytryptamine in the pig: evidence for the presence of vascular 5-Hydroxytryptamine, - like receptors, NaunynSchmiedeberg's Arch. Pharmacol. 333, 198.

Saxena, P.R., M.D. Ferrari, P. De Vries and C.M. Villalón, 1996, Pharmacological overview of new 5-HT $\mathrm{T}_{1 \mathrm{D}}$ receptor agonists in development for the acute treatment of migraine, in: Headache Treatment: Trial Methodology and New Drugs, eds. J. Olesen and P. Tfelt-Hansen (Lippincott-Raven Publishers, Philadelphia) (in press).

Schamhardt, H.C., P.D. Verdouw, T.M. Van Der Hoek and P.R. Saxena, 1979, Regional myocardial perfusion and wall thickness and arteriovenous shunting after ergotamine administration to pigs with a fixed coronary stenosis, J. Cardiovasc. Pharmacol. 1, 673.

Schoeffter, P. and D. Hoyer, 1989, How selective is GR 43175? Interactions with functional $5-\mathrm{HT}_{1 \mathrm{~A}}, 5-\mathrm{HT}_{1 \mathrm{~B}}, 5-\mathrm{HT}_{1 \mathrm{C}}$ and $5-\mathrm{HT}_{1 \mathrm{D}}$ receptors, Naunyn-Schmiedeberg's Arch. Pharmacol. 340, 135.

Schoeffter, P. and D. Hoyer, 1990, 5-Hydroxytryptamine (5-HT)-induced endothelium-dependent relaxation of pig coronary arteries is mediated 
by $5-\mathrm{HT}$ receptors similar to the $5-\mathrm{HT}_{1 \mathrm{D}}$ receptor subtype, J. Pharmacol. Exp. Ther. 252, 387.

Skingle, M., D.I.C. Scopes, W. Feniuk, H.E. Connor, M.C. Carter, J.W Clitherow and M.B. Tyers, 1993, GR127935: a potent orally active 5-HT ${ }_{1 \mathrm{D}}$ receptor antagonist, Br. J. Pharmacol. 110, 9P.

Sonesson, C., M. Boije, K. Svensson, A. Ekman, A. Carlsson, A.G. Romero, I.J. Martin, J.N. Duncan, L.J. King and H. Wikström, 1993, Orally active central dopamine and serotonin receptor ligands: 5-, 6-, 7-, and 8-[[trifluoromethyl)sulfonyl]oxy]-2-(di- $n$-propylamino)tetralins and the formation of active metabolites in vivo, J. Med. Chem. 36, 3409.

Sonesson, C., T. Barf, J. Nilsson, D. Dijkstra, A. Carlsson, K. Svensson, M.W. Smith, I.J. Martin, J.N. Duncan, L.J. King and H. Wikström, 1995, Synthesis and evaluation of pharmacological and pharmacoki- netic properties of monopropyl analogues of 5-, 7- and 8-[[trifluoromethyl)sulfonyl]oxy]-2-aminotetralins, J. Med. Chem. 38, 150.

Spierings, E.L.H, and P.R. Saxena, 1980, Antimigraine drugs and cranial arteriovenous shunting in the cat, Neurology $30,696$.

The Subcutaneous Sumatriptan International Study Group, 1991, Treatment of migraine with sumatriptan, New Engl. J. Med. 325, 316.

Van Es, N.M., T.A. Bruning, J. Camps, P.C. Chang, G.J. Blauw, M.D. Ferrari, P.R. Saxena and P.A. Van Zwieten, 1995, Assessment of peripheral vascular effects of antimigraine drugs in humans, Cephalalgia $15,288$.

Watson, J., M. Burton, G.W. Price, B.J. Jones, D. Thomas, A. Faruq and D.N. Middlemiss, 1995, GR127935 acts as a partial agonist at recombinant human $5-\mathrm{HT}_{\mathrm{ID} \alpha}$ and $5-\mathrm{HT}_{\mathrm{ID \beta}}$ receptors, Br. J. Pharmacol. $114,362 \mathrm{P}$. 